\title{
A severe Case of Hypercalcemia due to Pulmonary Tuberculosis Reactivation
}

\section{Reaktivasyon Akciğer Tüberkülozuna Bağlı Ciddi Hiperkalsemi Olgusu}

Şule Gül', Ali Çetinkaya', Yağmur Başhan², Mehmet Atilla Uysal'

\begin{abstract}
A 42-year-old female patient who was treated for pulmonary tuberculosis three years ago was admitted to our clinic with complaints of muscle weakness. On chest radiography, a diffuse cavitary lesion and nodular infiltration of the right lung was detected. Sputum acid-fast bacilli were positive, and the patient was diagnosed with pulmonary reactivation tuberculosis. Severe hypercalcemia was observed in the laboratory, and treatment for hypercalcemia was started alongside tuberculosis treatment. The case was presented to literature due to its rarity.
\end{abstract}

Key words: Granuloma, hypercalcemia, tuberculosis.

\section{Özet}

Üç yıl önce tüberküloz tedavisi alan 42 yaşında bayan hasta, polikliniğimize kas güçsüzlüğü şikâyeti ile başvurdu. Akciğer grafisinde, sağ akciğerde yaygın kaviter ve nodüler infiltrasyon mevcuttu. Balgam aside dirençli boyaması (ARB) pozitif gelen hastaya reaktivasyon akciğer tüberkülozu tanısı kondu. Laboratuvar sonuçlarında ciddi hiperkalsemi saptanan hastaya, tüberküloz tedavisinin yanında hiperkalsemi tedavisi başlandı. Olgu nadir görülmesi nedeniyle literatür eşliğinde sunuldu.

Anahtar Sözcükler: Granülom, hiperkalsemi, tüberküloz.
'Department of Chest Diseaes, Yedikule Chest Diseases and Chest Surgery Education and Research Hospital, İstanbul, Turkey ${ }^{2}$ Department of Internal Diseases, Samatya Education and Re- search Hospital, İstanbul, Turkey
'Yedikule Göğüs Hastalıkları ve Göğüs Cerrahisi Eğitim ve Araştırma Hastanesi, Göğüs Hastalıkları Bölümü, İstanbul ${ }^{2}$ Samatya Eğitim ve Araştırma Hastanesi, İç Hastalıkları AD, İstanbul

Submitted (Başvuru tarihi): 21.06.2018 Accepted (Kabul tarihi): 12.12.2018

Correspondence (iletişim): Şule Gül, Department of Chest Diseaes, Yedikule Chest Diseases and Chest Surgery Education and Research Hospital, İstanbul, Turkey

e-mail: suleeyhan@gmail.com 
Hypercalcemia is an electrolyte disturbance that is usually self-evident due to its neuromuscular symptoms. While the most common cause is primary hyperparathyroidism, malignancy is common in severe cases of hypercalcemia requiring hospitalization (1). Hypercalcemia due to granulomatous disease is a clinical condition that is encountered less frequently; while hypercalcemia due to tuberculosis is usually more mild and asymptomatic (2). We present here a severe case of hypercalcemia resulting from pulmonary reactivation tuberculosis.

\section{CASE}

A 42-year-old female patient with a history of pulmonary tuberculosis three years previously was admitted to our clinic with complaints of muscle weakness. She had no another medical history and was taking no regular medication. The initial vital signs were within normal limits. In a respiratory examination, decreased breathing sounds in the left lung and crackles in the right lung were detected. In the laboratory tests, serum calcium (corrected with albumin level) was recorded as $14.6 \mathrm{mg} / \mathrm{dL}$ and the patient was admitted to our service. In the other tests, phosphate $3.4 \mathrm{mg} / \mathrm{dl}$ (normal: 2.5-4.5), magnesium 1.7 $\mathrm{mg} / \mathrm{dl}$ (normal: 1.2-2.5), alkaline phosphatase (ALP) 99 IU/L (normal: 25-130) and 25-hydroxyvitamin D 48 $\mathrm{ng} / \mathrm{ml}$ (normal $>20$ ) were in the normal range. Parathyroid hormone was decreased to $6.3 \mathrm{pg} / \mathrm{ml}$ (normal: 15 75); albumin was decreased to $2.1 \mathrm{~g} / \mathrm{dl}$ (normal: 3.2 5.2); and 1.25-hydroxyvitamin D was elevated at 153 $\mathrm{pg} / \mathrm{ml}$ (normal: 26-94). A chest radiography revealed a destroyed lung view in the left lung, alongside diffuse cavitary and nodular infiltration in all zones of the right lung (Figure 1). In a thorax computed tomography, diffuse bilaterally cavitary lesions and loculated fluid appearance caused air-fluid leveling (Figure 2). Sputum acid-fast bacilli were positive, and the patient was diagnosed with pulmonary reactivation tuberculosis. Antituberculosis treatment was started with isoniazid $300 \mathrm{mg}$, rifampicin $450 \mathrm{mg}$, ethambutol $1000 \mathrm{mg}$, pyrazinamide $1500 \mathrm{mg}$ and streptomycin $750 \mathrm{mg}$. For hypercalcemia, intravenous fluids and loop diuretics were administered immediately.

For a differential diagnosis and ultrasound of the neck, thorax and abdomen, computed tomographies were performed. The patient was denied any calcium, vitamin $D$, vitamin A or thiazides. Malignancies and endocrinopathies were excluded with clinical-biochemical and radiological findings. The hypercalcemia was considered serious due to the pulmonary tuberculosis.

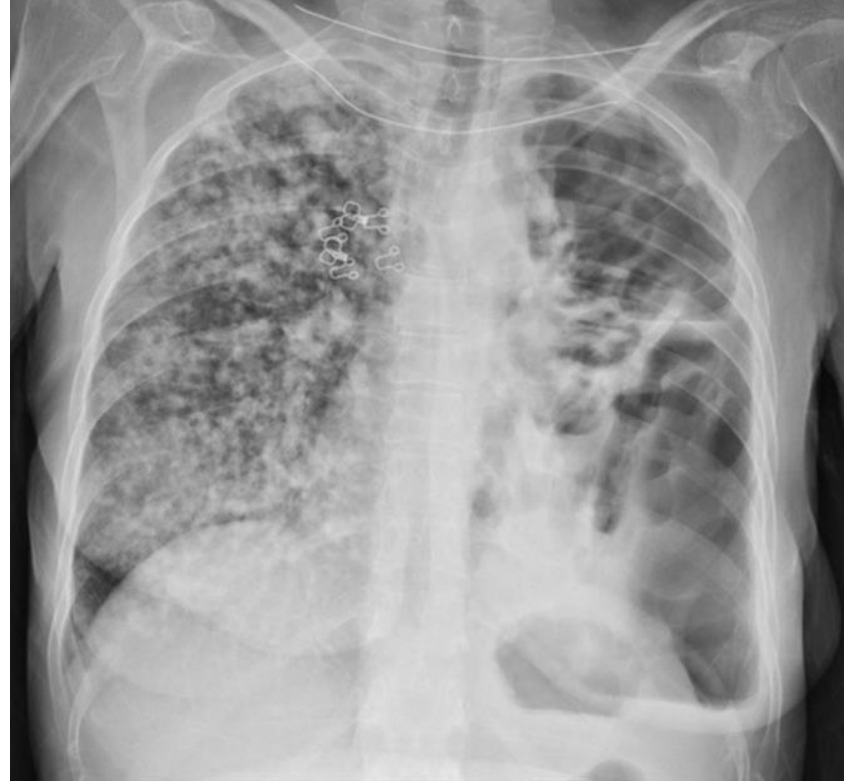

Figure 1: In chest $X$-ray destroyed lung view in the left lung and diffuse cavitary and nodular infiltration in all zones of the right lung

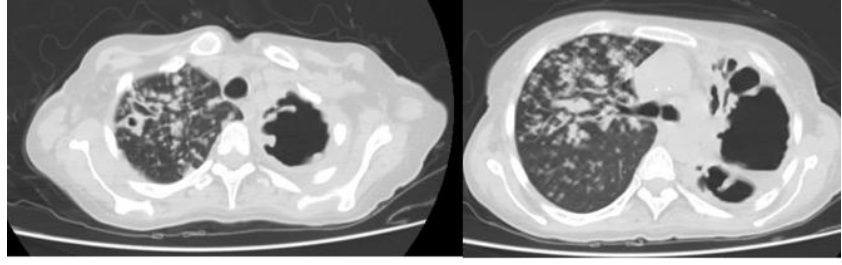

Figure 2: Thorax computed tomography: diffuse bilaterally cavitary lesions and infiltrations

On the third day of treatment with fluid and diuretics, serum calcium levels decreased to $13 \mathrm{mg} / \mathrm{dl}$, and $40 \mathrm{mg}$ methylprednisolone was added to treatment. On the sixth day of treatment, serum calcium levels decreased to 9 $\mathrm{mg} / \mathrm{dl}$ with no need for biphosphonate treatment. Steroid treatment was halted, and with anti-tuberculosis treatment, no further was seen.

\section{DISCUSSION}

Severe hypercalcemia requiring treatment is rare in granulomatous diseases like tuberculosis. In the present study we present a case report of a patient with severe hypercalcemia due to pulmonary reactivation tuberculosis. Hypercalcemia due to tuberculosis is usually milder and asymptomatic (2), while hypercalcemia in granulomatous diseases is associated with the abnormal extra renal production of 1,25-dihydroxyvitamin D3 by activated macrophages in granulomatous tissue. In normal situations, vitamin D3 is absorbed by the skin from ultraviolet $B$ light. Vitamin D3 is first metabolized into 25-hydroxyvitamin D [25OHD3] in the liver with 25-hydroxylase. In the kidney, $25 \mathrm{OHD} 3$ catalyzed via $1 \alpha$-hydroxylase to active form 1,25-dihydroxyvitamin D3. In tuberculosis and other 
granulomatous diseases, gamma interferon-activated T lymphocytes and alveolar macrophages produce $1 \alpha$ hydroxylase that cause the extra renal production of 1,25dihydroxyvitamin D3. This increases the enteric absorption of calcium $(2,3)$.

Roussos et al. (4) identified a hypercalcemia rate of $25 \%$ in their tuberculosis patients in the Greek population, although the incidence rate varies between 15 and $51 \%$ in different studies (4-7), with the highest rate recorded in Australia (7). It has been shown that symptoms associated with hypercalcemia are rare among hypercalcemic tuberculosis patients (4). In a study from Turkey by Deniz et al. (8), parathormone levels and hypercalcemia were compared in terms of radiological extent, and in 44 tuberculosis patients, hypercalcemia was found to be common, although the sample contained no severe hypercalcemia patient. The patient in the present study had muscle weakness and severe hypercalcemia.

In several studies, hypercalcemia in TB patients has been associated with the extent of the disease, vitamin $D$ and calcium intake, and the amount of sun exposure. The different rates reported in different countries can be attributed to the above reasons. One possible explanation is that TB patients with relatively high vitamin D levels have more circulating vitamin $D$ available for the extrarenal synthesis of 1,25-dihydroxyvitamin D3 than others (9). If the calcium intake is high, the gut absorption of calcium is also relatively high. Aside from the ingestion route, in tropical climates, where sun exposure is high, concentrations of $25(\mathrm{OH}) \mathrm{D} 3$ are increased $(4,9)$. Vitamin D3 (cholecalciferol) is synthesized from 7-dehydrocholesterol in the skin during exposure to ultraviolet light. The amount of sun exposure and the circulating levels of $25(\mathrm{OH}) \mathrm{D} 3$, as a product of hydroxylation of vitamin D3 in the liver, may partly explain the rare occurrence of hypercalcemia in TB patients in countries with temperate climates. In our patient, we found that 1,25- dihydroxyvitamin D3 was elevated and that the parathyroid hormone was decreased.

In our country, sun exposure and vitamin D intake rates are low, and the less frequent occurrence of hypercalcemia in patients with tuberculosis may be a result of this. In our patient, the radiological extent of the tuberculosis and the previous bout of tuberculosis might have increased the risk of hypercalcemia.

Prior to beginning treatment, other causes of hypercalcemia, such as hyperparathyroidism, malignancies, medication and endocrinopathies, must be excluded, especially in the elderly. For treatment, fluid replacement, diuretics, steroids and bisphosphonates are recommended, based on the patient's clinical and laboratory status $(2,10)$. The patient in the present study was treated with steroids for 6 days and fluids-diuretics for 14 days. At the end of this therapy, serum calcium levels reached normal levels.

On the other hand, vitamin D deficiencies can be seen in tuberculosis patients at the time of diagnosis, and vitamin $D$ may reduce with treatment. In some studies, vitamin D supplementation led to radiologic and microbiological improvement, and so vitamin D supplementation to therapy was recommended (11). Recent guidelines suggest maintaining a $25(\mathrm{OH}) \mathrm{D}$ level of between 20 and 30 $\mathrm{ng} / \mathrm{ml}$ in patients with granulomatous disorders, although in doing so, the close monitoring of $25(\mathrm{OH}) \mathrm{D}$ levels is recommended, and levels of more than $30 \mathrm{ng} / \mathrm{ml}$ should be avoided, being associated with hypercalcemia and hypercalciuria. Serious hypercalcemic crises can occur during treatment (12).

\section{CONCLUSION}

As severe hypercalcemia with active tuberculosis is a rare condition, it must be kept in mind as a differential diagnosis. Measuring calcium levels during tuberculosis treatment may be beneficial.

\section{CONFLICTS OF INTEREST}

None declared.

\section{AUTHOR CONTRIBUTIONS}

Concept - Y.B., M.A.U., Ş.G., A.Ç.; Planning and Design - S..G., M.A.U., A.Ç., Y.B.; Supervision - Ş.G., M.A.U., A.Ç., Y.B.; Funding - A.Ç., Y.B.; Materials - A.Ç., Y.B.; Data Collection and/or Processing - A.Ç., Y.B., S..G.; Analysis and/or Interpretation - S.G., M.A.U.; Literature Review - S..G.; Writing - Ş.G., M.A.U.; Critical Review Ş.G., M.A.U.

\section{YAZAR KATKILARI}

Fikir - Y.B., M.A.U., S..G., A.Ç.; Tasarım ve Dizayn - Ş.G., M.A.U., A.Ç., Y.B.; Denetleme - Ş.G., M.A.U., A.Ç., Y.B.; Kaynaklar - A.Ç., Y.B.; Malzemeler - A.Ç., Y.B.; Veri Toplama ve/veya isşleme - A.Ç., Y.B., Ş.G.; Analiz ve/veya Yorum - S..G., M.A.U.; Literatür Taraması - S..G.; Yazıyı Yazan - S..G., M.A.U.; Eleştirel Inceleme - S..G., M.A.U. 


\section{REFERENCES}

1. Fisken RA, Heath DA, Somers S, Bold AM. Hypercalcemia in hospital patients: Clinical and diagnostic aspect. Lancet 1981; 1: 202-7. [CrossRef]

2. Chan JY, Kanthaya M. Hypercalcaemic crisis in an elderly patient with pulmonary tuberculosis. Oxf Med Case Reports 2015; 2015:354-7. [CrossRef]

3. Dayal D, Didel SR, Agarwal S, Sachdeva N, Singh M. Acute hypercalcaemia and hypervitaminosis $D$ in an infant with extra pulmonary tuberculosis. J Clin Diagn Res 2015; 9:SD03-4. [CrossRef]

4. Roussos A, Lagogianni I, Gonis A, Ilias I, Kazi D, Patsopoulos D, et al. Hypercalcaemia in Greek patients with tuberculosis before the initiation of anti-tuberculosis treatment. Respir Med 2001; 95:187-90. [CrossRef]

5. Chan TY, Chan CH, Shek CC. The prevalence of hypercalcaemia in pulmonary and miliary tuberculosis-a longitudinal study. Singapore Med J 1994; 35:613-5..

6. Liam CK, Lim KH, Srinivas P, Poi PJ. Hypercalcemia in patients with newly diagnosed tuberculosis in Malaysia. Int J Tuberc Lung Dis 1998; 2:818-23.
7. Need AG, Phillips PJ, Chiu F, Prisk H. Hypercalcaemia associated with tuberculosis. B Med J 1980; 280: 831. [CrossRef]

8. Deniz O, Tozkoparan E, Yonem A, Ciftci F, Bozkanat E, Cakir $E$, et al. Low parathormone levels and hypercalcaemia in patients with pulmonary tuberculosis: relation to radiological extent of disease and tuberculin skin test. Int J Tuberc Lung Dis 2005; 9:317-21.

9. Dosumu EA, Momoh JA. Hypercalcemia in patients with newly diagnosed tuberculosis in Abuja, Nigeria. Can Respir J ; 13:83-7. [CrossRef]

10. Waller M, Murphy S, Krishnarai N, Antunes G. Respiratory failure and symptomatic hypercalcaemia complicating pulmonary tuberculosis. BMJ Case Rep 2009; 2009. pii: bcr10.2008.1081. [CrossRef]

11. Naik AL, Rajan MG, Manirekar PA, Shenoy MT, Shreelata S, Srikantiah RM, et al. Effect of DOTS treatment on vitamin $D$ levels in pulmonary tuberculosis. J Clin Diagn Res 2017; 11:BC18-BC22. [CrossRef]

12. Sarathi V, Karethimmaiah H, Goel A. High-dose vitamin $D$ supplementation precipitating hypercalcemic crisis in granulomatous disorders. Indian J Endocrinol Metab 2017; 21:815-9. [CrossRef] 